\title{
Immunology of human leprosy-current status
}

\author{
INDIRA NATH \\ Department of Pathology, All India Institute of Medical Sciences, \\ New Delhi-110029, India
}

It gives me great pleasure to contribute to a volume honouring Dr RJW Rees. Just over a decade ago, as a Nuffield Fellow, I first met him in an art gallery, at a party hosted by the British Society of Immunology. Over the years, like many others, I worked with him and learned a great deal about leprosy as well as human values. His ability to cross national borders and interact with leprosy workers of diverse interests and motivations has been invaluable in developing constructive group activity. His immediate response to a frantic call for reagents/chemicals has made our personal research work possible. My colleagues and I wish him many years of continued productive work in leprosy.

\section{Introduction}

In the last decade leprosy has proved to be an intriguing challenge to immunologists. Though absolute proof regarding the non-variability in the pathogenicity of Mycobacterium leprae is not available, it is generally conceded that the spectrum of clinical types seen in leprosy is due to variation in host immunity. Prolonged and sustained antigenic stimulation with leprosy bacillus leads to a complex array of immunological responses. The end result is reflected as a wide spectrum of immunopathological aberrations. Both humoral and cellular responses are elicited and immune-complexes have been seen in the circulation of leprosy patients. Since $M$. leprae is located intracellularly, cell-mediated responses may be more important for its elimination. Effective immunity and high resistance appear to be linked to T-cell functions. The mechanisms responsible for the non-responsiveness, particularly of the antigenspecific type, are being gradually unravelled. In recent years progress has been made in relation to HLA-linked genes, cells mediating suppression, antigenic components of $M$. leprae and possible tools for the diagnosis of subclinical infection. 
Ridley \& Jopling ${ }^{1}$ introduced a classification of clinical leprosy based on the concept that it was a five-point spectral disease. Tuberculoid individuals of polar (TT) and borderline (BT) type have paucibacillary, localized self-limiting disease whereas the patients with lepromatous leprosy (polar LL and borderline BL) have disseminated multibacillary disease which requires long-term chemotherapy. The borderline forms of this disease (BT, BB and BL) are unstable in their immunological responsiveness and prone to reactions. Most of the studies described in this review have used the above classification. The present review is limited to the progress made in the last 5 years in the understanding of the immunological aspects of leprosy. The reader is referred to earlier excellent reviews for investigations prior to this time, ${ }^{2,3}$ and other articles in this volume pertaining to reactions and immunoprophylaxis.

\section{Nature of the causative organism}

\section{SPECIES-SPECIFIC ANTIGENS OF Mycobacterium leprae}

The identity of species-specific antigens of $M$. leprae with biological activity has received impetus since the availability of infected armadillo tissues, containing abundant bacilli. Comparison of armadillo and human-derived $M$. leprae showed similarity in delayed hypersensitivity tests ${ }^{4}$ and in lymphocyte transformation tests in leprosy patients. ${ }^{5}$ The immunogenicity and heat stability of the armadillo-derived bacilli was also established. ${ }^{6}$ That some antigens were lost due to treatment with alkali and pronase during purification of bacilli from liver tissue led to the adaptation of improved procedures. ${ }^{7,8}$ In most studies the biological relevance of these antigens has been established by demonstrating the presence of antibodies directed against these components in leprosy sera.

Earlier studies ${ }^{9}$ using indirect immunofluorescence have been confirmed ${ }^{10}$ and indicated that antibodies recognizing $M$. leprae specific antigens were present in patients across the leprosy spectrum. A search for protein antigens with sensitive techniques has revealed both cross-reacting and species-specific components in $M$. leprae. Lepromatous sera as well as hyperimmune sera from immunized rabbits showed 7 distinct bands which cross-reacted with other mycobacteria. ${ }^{11,12}$ Subsequently it was shown that antigen 7, which was equivalent to antigen 60 of $\mathrm{BCG}$, was recognized by the patients' sera. Moreover, acetone-killed $M$. leprae from the armadillo tissues was shown to have a protein antigen which was resistant to heat and pronase treatment. ${ }^{11}$ The application of hybridoma technology is expected to produce monoclonal antibodies which may be helpful in dissecting the various antigenic components of $M$. leprae. Gillis \& Buchanan ${ }^{13}$ reported the production of 11 monoclonal antibodies which reacted against $M$. leprae and 18 other mycobacteria as assessed by ELISA and immunofluorescence techniques. Of these, two seemed to be specific for M. leprae. Other workers using SDS-PAGE fractionation of armadillo-derived $M$. leprae antigen and then 
reacting them with antibodies in lepromatous sera, detected two specific antigenic bands of $33 \mathrm{KD}$ and $12 \mathrm{KD} .{ }^{14}$

As early as 1970 it had been reported that lepromatous patients had antibodies which reacted with phospholipids (namely, mannophosphoinositides) of $M$. tuberculosis. ${ }^{15}$ Recently, attention has been drawn to the presence of $M$. leprae specific lipid antigens with biological activity. Lipids of bacterial origin were shown to be present in the lesional skin of leprosy patients. ${ }^{16,17} \mathrm{~A}$ species-specific lipid antigen in infected armadillo tissues has been reported. ${ }^{18} \mathrm{It}$ has been chemically characterized to be related to phenolic mycoside A. The distinctiveness, uniqueness and species-specificity of this phenolic glycolipid lies in the trisaccharide appendage. The only other closely related component would seem to be the mycoside A from M. kansasii, though it shows some differences in the oligosaccharide composition and mobility on thin-layer chromatography. This lipid antigen is present in large amounts in the infected armadillo tissues $(2 \cdot 2$ $\mathrm{mg} / \mathrm{g}$ dry weight of liver with $9 \times 10^{10} \mathrm{AFB} / \mathrm{g}$ ). It can be obtained even after the bacilli have been removed, suggesting that it may be responsible for the electron-transparent 'foam' surrounding the organisms in the tissues. That it is immunogenic has been indicated by the presence of antibodies recognizing phenolic glycolipid in $80 \%$ of leprosy patients. ${ }^{19-21}$ This antigen may serve as a unique marker to identify subclinical leprosy, though its biological relevance in the host immune response to the bacillus requires further investigation.

An implication that some antigenic components of $M$. leprae may selectively induce delayed-type hypersensitivity skin reactions has been suggested. ${ }^{22} \mathrm{An}$ anionic component of electrophoresed Dharmendra antigen, when injected intradermally in tuberculoid patients, produced delayed-type skin tests with a lympho-mononuclear infiltrate. The corresponding cationic component showed an early skin reaction with a predominant polymorphonuclear infiltration.

\section{Immune responses in patients with leprosy}

Both humoral and cell-mediated responses appear to be elicited by the pathogen in the human host. A decade of investigations has indicated that high resistance with concontaminant elimination of the organism as exemplified in tuberculoid leprosy is associated with good T-cell functions. The multibacillary low-resistant form of lepromatous leprosy is associated with enhanced humoral and reduced cellular responses. Moreover, it has been suggested that other environmental mycobacteria may modulate the immunological responses of the host to Mycobacterium leprae infection. Studies by Stanford et al. have drawn attention to the concept that protection induced by BCG as well as leprosy types may be related to the species of mycobacteria present in a given area to which the population is first exposed..$^{23,24}$ 


\section{(a) ANTIBODY RESPONSES IN LEPROSY}

Serum immunoglobulins, particularly of $\mathrm{IgG}$ class and other mycobacterial antibodies, had been consistently found to be raised in lepromatous leprosy individuals. Using sensitive, crossed immuno-electrophoresis (CIE), radioimmunoassays (RIA) and immunofluorescence, recent studies have indicated that $M$. leprae specific antibodies are seen throughout the leprosy spectrum, though the proportion of positive cases and the titres were highest at the lepromatous pole. Using a sensitive radioimmunoassay where $M$. leprae specific antibodies with titres of $10^{5}$ could be measured in a lepromatous serum pool, Harboe et al. reported that 61 of 62 polar lepromatous, all of 24 borderline sera and 20 of 48 tuberculoid were positive. On the other hand, 38 sera from control tuberculinpositive individuals from a leprosy non-endemic region were negative. ${ }^{25}$ In subsequent studies, the same group has identified antibodies to antigen 7 of $M$. leprae to be of significance and present in the sera of leprosy patients. ${ }^{12}$ Using purified preparation of this antigen it was shown that the antibodies were directed against determinants other than arabinogalactan and arabinomannan in 12 out of 14 lepromatous leprosy sera. ${ }^{25}$ Antibodies against antigen 7 appeared to be good markers of intrauterine infection in leprosy. ${ }^{26}$ By means of solid phase RIA, ${ }^{27-29}$ it was possible to identify the class specificity of $M$. leprae specific antibodies. High IgG anti-M. leprae antibody levels were detected in lepromatous leprosy. In tuberculoid leprosy they varied from negative to strongly positive in patients with active lesions. High levels of IgM anti-M. leprae antibodies were also found in lepromatous patients, which showed a marked fall in titres in the first year of treatment. It was further shown that as a result of intrauterine infection 30 and $50 \%$ of cord sera of children born to BL/LL mothers had IgA and IgM anti- $M$. leprae antibodies respectively. Babies born to tuberculoid mothers did not show specific antibodies. Interestingly, a few months af ter birth, children from both groups of mothers had similar levels of species-specific IgA and IgM, but reduced levels of $\operatorname{IgG}$ antibodies. ${ }^{28}$

The presence of anti-lipid antibodies has also been reported in untreated patients from Thailand. 9/9 LL, 2/2 BL, 5/10 BT and 7/8 TT patients were found to have significant levels of antibodies to the specific phenolic glycolipid antigen. The titre of antibodies was highest in the lepromatous group $(10 \cdot 8 \pm 4 \cdot 6)$ as compared to the tuberculoid patients $(2 \cdot 2 \pm 1 \cdot 9){ }^{21}$

Antibodies have been demonstrated not only in the blood of patients, but have also been shown to be locally synthesized in the lesional skin in vitro. IgG as well as M. leprae specific antibodies have been shown to be synthesized in the skin biopsies from lepromatous patients but not in tuberculoid individuals. ${ }^{30,31}$

In addition to the development of mycobacterial antibodies, the disease appears to elicit autoantibocies. Anti-Ig, anti-nuclear and anti-thyroid antibodies have been reported in many lepromatous patients. ${ }^{2}$ However, in one study no differences were noted in the incidence of autoantibodies in the control and 
patient population of California. ${ }^{32}$ Circulating antibodies to connective tissue microfibrils appear to be also present in lepromatous sera. ${ }^{33}$

\section{(b) CELL-MEDIATED IMMUNE RESPONSES}

It is now well established that $\mathrm{T}$-cell mediated responses provide effective immunity in leprosy. These responses are found to be intact in tuberculoid leprosy and show a graded reduction towards the lepromatous pole. A general impairment of $\mathrm{T}$-cell functions has been reported in some lepromatous patients and refuted in others. ${ }^{3,34}$ However, there is universal agreement that patients of polar lepromatous leprosy show long lasting anergy to specific antigens as judged by in vivo skin tests and in vitro lymphocyte functions. Details of earlier studies have been extensively reviewed elsewhere. ${ }^{2,3}$

In recent years it has been suggested that the lymphocyte transformation test (LTT), considered to be an in vitro correlate of cell-mediated immunity, may be measuring hypersensitivity rather than the resistance status of the patients. ${ }^{35,36}$ LTT in babies has been reported to be depressed by plasma factors from leprosy mothers ${ }^{37}$ and in individuals receiving DDS (dapsone $4^{\prime}, 4^{\prime}$-diaminodiphenyl sulphone). ${ }^{38}$ An interesting study has indicated that a natural killer cell activity was depressed during erythema nodosum leprosum though not altered in the stable form of the disease. ${ }^{39}$

\section{Diagnosis of subclinical infection}

Apart from indicating the status of humoral immunity, Mycobacterium leprae specific antibodies could be used for the early detection of subclinical infection in the community, obviating the operational problems inherent in large-scale delayed hypersensitivity and T-cell function tests. Most of the antibody detecting systems employed in the above studies could be utilized for this purpose. Where possible, lepromin testing could be combined with antibody assays to evaluate high risk groups.

Abe et $a l .{ }^{40}$ and Bharadwaj et al., ${ }^{41}$ using indirect immunofluorescence, showed that healthy contacts of leprosy patients had detectable $M$. leprae specific antibodies. In addition, the latter compared antibody and lepromin reactions and found that $52 \%$ of individuals with positive serology showed negative lepromin reactions and may thus constitute a high risk group. A similar study using ELISA to estimate antibodies and skin tests with various antigens investigated the relationship of these parameters to protective immunity in an Iranian population. ${ }^{42}$

Studies using crossed immunoelectrophoresis, ${ }^{11,}{ }^{12}$ radioimmunoassay, ${ }^{25}$ solid phase radioimmunoassay, ${ }^{27-9}$ ELISA for mycobacterial and phenolic glycolipid antigens ${ }^{21}$ have been developed with a view to detecting early infection. Results on 
follow-up studies are awaited to evaluate the relative merits of the presently available systems.

\section{Mechanisms for unresponsiveness in leprosy}

The mechanisms underlying the depression of host immune responses in leprosy have yet to be elucidated. Recent studies in this field have investigated the role of (a) suppressor T cells, (b) adherent cells, and (c) HLA-linked genetic factors.

\section{(a) ROLE OF SUPPRESSOR T CELLS}

Since the demonstration of a subpopulation of murine $T$ cells which exert immune regulation by suppressing immune responses ${ }^{43}$ an avalanche of publications is available on the role of these cells in the normal and diseased states. Investigators working independently and concurrently in Ethiopia, India and the USA have investigated the role of suppressor cells in human leprosy. Bjune, ${ }^{44}$ working on a well-defined population in Ethiopia, showed that Mycrobacterium leprae antigens in general suppressed the in vitro PHA responses of all leprosy patients and healthy contacts.

Mehra et al. ${ }^{45}$ using patients from the USA, showed that the addition of Dharmendra antigen-suppressed Con A induced lymphocyte transformation selectively in lepromatous and not in tuberculoid patients or healthy individuals. They further showed that this suppression was due to the classical suppressor $\mathrm{T}$ cells bearing $\mathrm{TH} 2+{ }^{46}$ and $\mathrm{T} 8+$ phenotypic markers. ${ }^{47}$ Using the fluorescent cell sorter, they were able to show that these cells functionally suppressed the mitogenic responses of allogeneic lymphocytes from healthy individuals. These workers implied that suppressor $\mathrm{T}$ cells were responsible for the lack of cellular immune responses in lepromatous leprosy. However, these studies did not clearly define the treatment status, and the ethnic nature of the patients studied. These factors are important if immune regulation is being studied at a given point of time during chronic infection.

Nath et al. studied untreated patients from a hyperendemic and a low endemic area of India and used four different methodologies for suppressor cell activity. Care was taken to ensure HLA compatibility in cell mixture studies. Concanavalin A-induced suppressor cell activity was found to strongly and selectively suppress autologous mitogenic responses of tuberculoid patients but not that of lepromatous leprosy individuals. ${ }^{48} M$. leprae antigen suppressed Con A stimulated lymphocyte transformation in the majority of tuberculoid, but only in a few lepromatous patients. Many of the latter as well as healthy contacts showed enhanced responses. These differential effects were observed on day 4 of culture. If the cultures were prolonged to 6 days the results confirmed the findings of Bjune $^{44}$ in that suppression was uniformly noted in all individuals. ${ }^{49}$ Moreover, 
enumeration of $\mathrm{T}$ cells with $\mathrm{Fc}$ receptors for $\mathrm{IgG}$ - thought to represent a suppressor $\mathrm{T}$-cell subset ${ }^{50}$ - showed normal values in tuberculoid and reduction in lepromatous patients. ${ }^{51}$ These studies, therefore, would indicate that suppressor T-cell activity was generated during infection with $M$. leprae in individuals with high resistance and capable of strong cellular immune reactions. They may serve to inhibit reactions and unwanted antibody formation. Suppressor cells have been reported to frequently develop during a strong immune response. ${ }^{52}$ The lack of suppressor T-cell activity in lepromatous leprosy may explain the excessive production of antibodies and autoantibodies, a situation analogous to systemic lupus erythematosus where suppressor cells have been found to be reduced. The above results were definitively confirmed in further studies on siblings of leprosy families. Using HLA-D matched lymphocyte-lymphocyte co-cultures, it was shown that tuberculoid leprosy individuals had natural suppressor lymphocytes that inhibited antigen and mitogen responses of HLA identical siblings. Lepromatous individuals lacked such cells in the circulation. ${ }^{53}$ Though the preferential migration of suppressor cells away from the blood to other sites cannot be ruled out, the paucity of absolute numbers of cells with phenotypic T8 markers in lepromatous lesions would suggest that the skin is not a major site. ${ }^{54}$

A lack of suppressor $T$ cells in lepromatous leprosy has also been reported from Ethiopia. ${ }^{55}$ There was a gradual development of $M$. leprae-induced suppressor activity in healthy individuals exposed to subclinical infection, implying an association of suppressor cell activity with resistance to leprosy infection. ${ }^{56}$ Bullock et al. also studied patients resident in the USA and found that T8 + (suppressor/cytotoxic) cells from lepromatous donors when co-cultured with normal B cells failed to suppress the response to pokeweed mitogen. They also postulated a loss of regulatory function by $\mathrm{T} 8+$ suppressor $\mathrm{T}$ cells in lepromatous patients. ${ }^{56 \mathrm{~b}}$ Studies in Carville, USA, also indicate that suppressor cell activity is associated with tuberculoid and not lepromatous individuals. ${ }^{57}$ Moreover, armadillos with disseminated disease lack suppressor activity whereas those resistant to repeated reinfection possessed suppressor T-cell function (EJ Shannon, personal communication). Functional studies have been more valuable in elucidating this phenomenon than studies on phenotypic markers for functional subsets of $\mathrm{T}$ cells. The numbers of $\mathrm{T} 3+$ (pan $\mathrm{T}$ cells), $\mathrm{T} 4+$ (helper/inducer) and T8 + (suppressor/cytotoxic) cells seem to be the same in all leprosy types ${ }^{58}$ (and personal observations). As indicated elsewhere these markers were of value in the study of lesions.

Thus it would seem that most of the studies on defined populations of leprosy patients show that suppressor T-cell activity is generated during strong cell-mediated immune responses in high-resistant individuals as part of the natural course of $M$. leprae infection. The lack of this activity is commonly observed in disseminated leprosy, indicating that suppressor $\mathrm{T}$ cells may be helpful in inhibiting unwanted antibody production and allergic reactions. 


\section{(b) ROLE OF ADHERENT CELLS/MACROPHAGES}

$M$. leprae reside within cells of the mononuclear phagocyte series and lead to granulomatous reaction in the host. The earlier claim, ${ }^{59}$ that macrophages from lepromatous individuals have an inherent defective killing capacity has been refuted by others. ${ }^{60,61}$ The methodology used in these studies may not have been sensitive enough to assess $M$. leprae viability/multiplication.

Using allogeneic macrophage-lymphocyte cell combinations, Hirschberg drew attention to defective macrophage function in lepromatous patients which inhibited $M$. leprae-stimulated lymphocyte transformation. ${ }^{62}$ Nath et al., using HLA-D identical co-cultures, confirmed these findings. In addition, they showed that lepromatous lymphocytes when combined with tuberculoid macrophages responded to $M$. leprae antigens, indicating thereby the presence of antigen-reactive $\mathrm{T}$ cells in lepromatous leprosy. ${ }^{53}$ Additional studies from our laboratory have confirmed the above and indicate that antigen processing by lepromatous macrophages is capable of inducing $M$. leprae lymphocyte transformation in HLA-compatible tuberculoid individuals. In addition, we have evidence to show that adherent cells in the peripheral blood of lepromatous individuals with macrophage characteristics exert suppressive effects on antigen-induced lymphocyte transformation of tuberculoid patients and healthy contacts. ${ }^{63}$ This suppression appears to be mediated by soluble factors from macrophages.

Studies from another group in India indicate that lepromatous macrophages show receptor, biochemical and functional alterations after phagocytosis of viable but not killed $M$. leprae. Protein synthesis as assessed by $3 \mathrm{H}$-leucine uptake has been shown to be selectively defective in the macrophages from lepromatous patients. ${ }^{64}$ Such macrophages show a reduction in the density of Fc receptors on exposure to $M$. leprae and not to other mycobacteria. ${ }^{65}$ Lysates from these macrophages reduced the protein synthesis of normal macrophages and inhibited lymphocyte transformation. ${ }^{66}$

The recent studies refuting a macrophage defect ${ }^{63}$ are not necessarily in conflict with the above results since our experience has shown that the concentration of macrophages required to constitute in vitro responses may vary from individual to individual and dose-related assays are required in these studies.

The above data taken together suggests that macrophages may negatively modulate in vitro lymphocyte responses and may contribute to the non-responsiveness seen in lepromatous leprosy. It is not possible as yet to comment on whether this defect is inherent, HLA-linked, or secondary to the disease. However, a macrophage defect alone may not explain the specific antigen-related unresponsiveness, unless mediated through specific $\mathrm{T}$ cells.

\section{(c) THE ROLE OF HLA}

Following the observations that the resistance of mice to certain antigen/virus was controlled by genes linked to the histocompatibility genes, intensive efforts 
are in progress to find a causal relationship between HLA and human disease. The diverse clinical types in leprosy related to the varied host responses to $M$. leprae would suggest an association of leprosy with genes linked to immune responsiveness. However, a number of population studies carried out in various ethnic groups seeking an association with HLA-A, -B and -C antigens have not provided a clear-cut pattern in leprosy. ${ }^{67-73}$

Using the argument that susceptibility to leprosy may be HLA linked but not necessarily identical to the HLA-A and -B alleles, De Vries et al. studied siblings and parents of multicase families in the Surinam population and thereby observed a haplotype association with leprosy. Though no association was found with a particular HLA-A-B-C antigen or haplotype, yet siblings affected with tuberculoid leprosy shared a parental haplotype with a higher frequency than expected.$^{74}$ These results were confirmed in another ethnic population of Wardha, India. ${ }^{75}$ Similar association was also observed in tuberculoid siblings of 75 families of South India where neither parent was diseased. ${ }^{76}$

HLA-D is thought to be the human equivalent for the murine immune response genes (Ir). Studies on HLA-D-related (DR) antigens in the Wardha area showed that siblings affected with tuberculoid leprosy inherited DRW2 significantly more often than was expected. The frequency of DRW6 on the other hand was much less. These findings suggested that susceptibility and resistant genes for tuberculoid leprosy was linked to DRW2 and DRW6 respectively. ${ }^{75,77}$ However, no such association with DR2 could be found when non-familial sporadic tuberculoid leprosy patients were compared with a well-matched normal control population. ${ }^{78}$ This apparent discrepancy was due to the fact that the control population of that area had a high frequency of DR2. It is possible that the high prevalence of tuberculoid leprosy seen in this area may be linked to the high frequency of DR2 in the general population. A similar though less marked increase in frequency of DR2 was reported in Mexican borderline tuberculoid patients. ${ }^{79}$ On the other hand, in the Japanese studies, both tuberculoid and lepromatous patients showed a higher frequency of DR2 ${ }^{80}$ It is interesting to note that in the Negroid-Caucasoid population of Surinam, HLA-DR3 was associated with tuberculoid leprosy and seemed to be protective against the low-resistant and unstable forms of leprosy. ${ }^{81}$

The Ethiopian studies examining the influence of HLA-D in M. lepraeinduced lymphoproliferative assays do not support the concept of an HLAlinked, specific unresponsiveness in leprosy. ${ }^{82}$ Nevertheless, it is possible that HLA-linked genes may play a role in determining the type of leprosy by regulating mechanisms of host responsiveness to $M$. leprae infection. The success of a leprosy vaccine may be dependent on further elucidation of this association.

\section{In situ characterization of cellular infiltrates in dermal lesions}

Membrane receptors present on lymphocytes and cells of the mononuclear 
phagocytes, as well as lysosomal enzymes, are useful markers for the identification of functional subsets of cells in cryostat sections of leprosy lesions. Ridley et al. reported that epithelioid cells of tuberculoid leprosy had C3 receptors and macrophages in lepromatous lesions lacked $\mathrm{C} 3$ but possessed receptors for the $\mathrm{Fc}$ fragment of $\mathrm{IgG}$, suggesting thereby that $\mathrm{Fc}$ receptors were lost on epithelioid cells. ${ }^{83}$ More recently, using haemoadsorption with AET-treated sheep erythrocytes, Gupta et al. found that the predominant lymphocyte in the leprosy granulomas was the $T$ cell. There was a graded reduction in the number of $T$ cells from tuberculoid to the lepromatous lesions. These workers did not find any differences in the density of $\mathrm{Fc}$ and $\mathrm{C} 3$ receptors on mononuclear phagocyte series across the leprosy spectrum.$^{84}$ Working independently, the same group ${ }^{54}$ and others ${ }^{85,86}$ confirmed the $\mathrm{T}$-cell nature of the lymphocytes by means of monoclonal antibodies to phenotypic markers of $\mathrm{T}$ cells and their subsets using indirect immunofluorescence and immunoenzymatic techniques. Moreover, it would appear that the proportion of T4 + (helper/inducer) to T8+ (suppressor/ cytotoxic) T cells was higher in tuberculoid lesions and varied from high to low in borderline and subpolar lepromatous leprosy. ${ }^{54,85}$ The few lymphocytes seen in polar lepromatous lesions were $\mathrm{T} 8+$. It is difficult to give a biological significance to the presence of $\mathrm{T} 8+$ cells in view of the paucity of absolute numbers of such lymphocytes in the lepromatous lesions. It was interesting to note that typical granulomas of tuberculoid leprosy had T $8+$ cells were arranged in a concentric manner in the mantle whereas T4 + cells were seen both in the mantle as well as scattered amongst the epithelioid cells. ${ }^{54,85}$ All three studies showed DR/Ia-like antigens on the lymphocytes and macrophages indicating the presence of activated $T$ cells and macrophages. Some epithelioid cells appeared to lack these antigens. ${ }^{54}$ Ridley, using formalin fixed tissues which may destroy these antigens, reported contradictory results showing a selective absence of Ia-like antigens on macrophages of lepromatous lesions. ${ }^{87}$ It would thus appear that activated T cells are the predominant lymphocytes in leprosy granulomas and are reduced in number from tuberculoid to lepromatous pole. B cells are infrequent in these lesions, ${ }^{88}$ (personal observations). The distinction between epithelioid cells and macrophages could not be determined fully by the surface markers used in the above studies.

\section{Immunomodulation of host responses}

With a view to improving the anergic state of lepromatous patients, several approaches at modulating immune responses have been undertaken.

Transfer factor therapy has been shown to produce temporary improvement in the form of positive skin tests and reversal reactions. ${ }^{89-92}$ Injection of leucocytes ${ }^{93}$ and thymus grafts ${ }^{94}$ had similar effects. It would appear that the injections of mycobacteria and particularly of BCG alone or with $M$. leprae are 
effective in converting to skin positivity, producing reversal reactions and causing clearance of bacilli. In recent years good results have been reported by repeated injections of BCG with $M$. leprae ${ }^{95,96}$ Positive skin tests and leucocyte migration inhibition have been reported in lepromin-negative patients injected with a saprophytic mycobacterium. ${ }^{97} \mathrm{~A}$ cultivable bacillus from leprosy skin grown in conditioned medium called ICRC bacillus has been shown to be immunogenic in mice and produce positive skin tests with bacterial clearance. ${ }^{98}$ Evaluation of the effectiveness and duration of immunomodulation in these studies is awaited. However, it is clear that partial restoration of some T-cell functions is possible by injection of armadillo-derived $M$. leprae and other mycobacteria. Their role in immunoprophylaxis will be discussed elsewhere in this volume.

\section{References}

1 Ridley DS, Jopling WH. Classification of leprosy according to immunity. A five group system. Int J Lepr, 1966; 34: 255-73.

2 Turk JL, Bryceson ADM. Immunological phenomena in leprosy and related diseases. $A d v$ Immunol, 1971; 13: 209.

3 Godal T. Immunological aspects of leprosy_present status. Prog Allergy, 1978; 25: 211 -42.

4 Bechelli LM, Haddad N, Pagnano PMC, Neves RG, Melchior E, Fregnan RC. Double blind trials to determine the late reactivity of leprosy patients and unaffected persons to different concentrations of armadillo lepromin in comparison to human lepromin. Int J Lepr, 1980; 48: 126-34.

5 Smelt AHM, Liew FY, Rees RJW. Lymphocyte response of leprosy patients to human-derived and purified armadillo-derived M. leprae. Clin exp Immunol, 1978; 34: 164-9.

6 Shepard CC, Walker LL, Van Landingham R. Heat stability of M. leprae immunogenicity. Infect Immun, 1978; 22: 87-93.

7 Draper P. WHO Report of the Fifth SWG Meeting on the Immunology of Leprosy, 1980. Annex. 4, TDR-IMMLEP-SWG (5) 80.3, Geneva, pp. 24-6.

8 Shepard CC, Draper P, Rees RJW, Lowe C. Effect of purification steps on the immunogenicity of M. leprae. Br J exp Path, 1980; 61: 376-9.

9 Abe M, Izumi S, Saito T, Mathur SK. Early serodiagnosis of leprosy by indirect immunofluorescence. Lepr India, 1976; 48: 272-6.

10 Bharadwaj VP, Ramu G, Desikan KV. Fluorescent leprosy antibody absorption (FLA-ABS) test for early serodiagnosis of leprosy. Lepr India, 1981; 53: 518-24.

11 Harboe M, Closs O, Bjorvatn B, Kronvall G, Axelson NH. The antibody response in rabbits to immunisation with M. leprae. Infect Immun, 1977; 18: 792-805.

12 Closs O, Mshana RN, Harboe M. Antigenic analysis of M. leprae. Scand J Immunol, 1979; 9: 297-302.

13 Gillis TP, Buchanan TM. Production and partial characterisation of monoclonal antibodies to M. leprae. Infect Immun, 1982; 37: 172-8.

14 Chakrabarty AK, Maire MA, Lambert PH. SOS-Page analysis of $M$. leprae protein reading with antibodies from sera of LL patients and infected armadillos. Clin exp Immunol, 1982; 49: 523-31.

15 Khuller GK, Subrahmanyam D. Antibodies to mannophosphoinositides in leprosy patients. Int J Lepr, 1970; 38: 365-8.

16 Young DB. Detection of mycobacterial lipids in skin biopsies from leprosy patients. Int J Lepr, 1981; 49: 198-204. 
17 Young DB. Mycobacterial lipids in infected tissue samples. Ann Microbiol (Inst Pasteur), 1982; 133B: $53-8$.

18 Brennan PJ, Barrow WW. Evidence of species-specific lipid antigens of M. leprae. Int J Lepr, 1980; 48: 382-7.

19 Hunter SW, Brennan PJ. A novel phenolic glycolipid from M. leprae possibly involved in immunogenicity and pathogenicity. J Bacteriol, 1981; 147: 728-35.

${ }^{20}$ Hunter SW, Brennan PJ. Novel glycolipid antigens from atypical mycobacteria. Fed Proc, 1982; 41: 1173 .

${ }^{21}$ Hunter SH, Fujiwara T, Brennan PJ. Structure and antigenicity of the major specific glycolipid antigen of M. leprae. J Biol Chem 1982; 257(24): 15072-79.

${ }^{22}$ Sengupta U, Sinha S, Ramu G, Mukherjee A, Desikan KV. Assessment of Dharmendra antigen V. Attempts for purification of specific skin delayed-type hypersensitivity inducing antigen(s) from lepromin. Lepr India, 1982; 54: 208-13.

${ }^{23}$ Stanford JL, Bahr GM, Nye PM, Rook G AW, Shield MJ. Common mycobacterial antigens may be important in leprosy. Proceedings Symposium on M. leprae, Bombay, February 1981.

${ }^{24}$ Stanford JL, Nye PM, Rook GAW, Samuel N, Fairbank A. A preliminary investigation of the responsiveness or otherwise of patients and staff of a leprosy hospital to groups of shared or species-specific antigens of mycobacteria. Lepr Rev, 1981; 52: 321-7.

${ }^{25}$ Harboe M, Closs O, Bjune G, Kronvall G, Axelson NH. Mycobacterium leprae specific antibodies detected by radioimmunoassay. Scand J Immunol, 1978; 7: 111-20.

${ }^{26}$ Melsom R, Duncan ME, Harboe M, Bjune G. Antibodies against M. leprae antigen 7 from birth to 18 months of age: an indicator of intrauterine infection in leprosy. Clin exp Immunol, 1980; 42: $107-13$.

27 Touw J, Langeridizk EMJ, Stoner GL, Belehu A. Humoral immunity in leprosy: IgG and IgM antibody responses to $M$. leprae in relation to various disease patterns. Infect Immun, 1982; 36: 885-92.

${ }^{28}$ Melsom R, Harboe M, Duncan ME: IgA, IgM, IgG anti-M. leprae antibodies in babies of leprosy mothers during first two years of life. Clin exp Immunol, 1982; 49: 532-42.

${ }_{29}$ Melsom R, Harboe M, Myrvang B, Godal T, Belehu A. Immunoglobulin class specific antibodies to $M$. leprae in leprosy patients, including the indeterminate group and healthy contacts as a step in the development of serodiagnosis of leprosy. Clin exp Immunol, 1982; 47: 225-33.

${ }^{30}$ Lai A Fat RF, Jin JC, Diesselhoff DM, Van Furth R. In vitro synthesis of humoral factors in lesional skin of leprosy patients. Infect Immun, 1979; 25: 891-5.

${ }^{31}$ Lai A Fat RF, Chan Pin Jin J, VanFurth R, Harboe M. In vitro synthesis of antimycobacterial antibodies in biopsies from skin lesions of leprosy patients. Infect Immun, 1980; 27: 297-301.

32 Rea TH, Quismorio FP, Harding B, Nies KM, Di Sara PJ, Levan NE, Friou GJ. Immunologic responses in patients with lepromatous leprosy. Arch Derm, 1976; 112: 791-800.

${ }^{33}$ Linder E, Lehto VP, Stenman S, Lindgvist K, Bjorvatn B, Bergguist R. Circulating antibodies to connective tissue microfibrils and dermal immunoglobulin deposits in leprosy. Clin Immunol Immunopath, 1979; 13: 1-8.

${ }^{34}$ Faber WR, Leiker OL, Nengerman IM, Zeijtemaker WP, Schellekens PTA. Lymphocyte transformation test in leprosy: decreased lymphocyte reactivity to $M$. leprae in lepromatous leprosy, with no evidence of a generalised impairment. Infect Immun, 1978; 22: 649.

35 Bjune G, Barnetson RS, Ridley DS, Kronvall G. Lymphocyte transformation test in leprosy: correlation of the response with inflammation of lesions. Clin exp Immunol, 1976; 25: 85-94.

36 Barnetson R St C, Bjune G, Pearson JMH, Kronvall G. Antigenic heterogeneity in patients with reactions in borderline leprosy. $\mathrm{Br}$ Med J, 1975; iv: 435-7.

37 Bjune G, Duncan E, Barnetson R St C, Melsom R. In vitro modulation of lymphocyte responses 
to PHA by plasma in mother and baby at the time of birth. Increased lymphocyte responses in babies of mothers with lepromatous leprosy. Clin exp Immunol, 1978; 32: 517-22.

38 Ghei SK, Sengupta U, Ramu G. PHA-induced transformation of peripheral blood lymphocytes in leprosy patients. Lep India, 1980; 52: 223-8.

${ }^{39}$ Humphres RC, Gelber RFI, Krahenbuhl JL. Suppressed natural killer cell activity during episodes of erythema nodosum leprosum in lepromatous leprosy. Clin exp Immunol, 1982, 49: $500-8$.

40 Abe M, Minagawa F, Yoshino Y, Ozawa T, Saikawa K, Saito T. Fluorescent leprosy antibody absorption test for detecting subclinical infection with M. leprae. Int J Lepr, 1980; 48: 109-19.

${ }^{41}$ Bharadwaj VP, Ramu G, Desikan K V. A preliminary report on subclinical infection in leprosy. Lepr India, 1982; 54: 220-7.

42 Stanford JL, Rook GAW, Samuel N, Madlener F, Khameini AA, Nemati T, Modabber F, Rees RJW. Preliminary immunological studies in search of correlates of protective immunity carried out on some Iranian leprosy patients and their families. Lepr Rev, 1980; 51: 303-14.

${ }^{43}$ Gershon RK. A disquisition on suppressor T cells. Trans Rev, 1975; 26: 170-85.

${ }^{44}$ Bjune G. In vitro lymphocyte stimulation in leprosy: simultaneous stimulation with $M$. leprae and PHA. Clin exp Immunol, 1979; 36: 479-87.

45 Mehra V, Mason LH, Fields JP, Bloom BR. Lepromin-induced suppressor cells in patients with leprosy. J Immunol, 1979; 123: 1813-17.

46 Mehra V, Mason LH, Rothman W, Reinherz E, Schlossman SF, Bloom BR. Delineation of a human T-cell subset responsible for lepromin-induced suppression in leprosy patients. $J$ Immunol, 1980; 125: 1183-8.

47 Mehra V, Convit J, Rubinstein A, Bloom BR. Activated suppressor T cells in leprosy. J Immunol, 1982; 129: 1946-51.

48 Nath I, Narayanan RB, Mehra NK, Sharma AK, Gupta MD. Concanavalin A-induced suppressor activity in human leprosy. J Clin Lab Immunol, 1979; 2: 319.

49 Nath I, Singh R. The suppressive effect of $M$. leprae on the in vitro proliferative responses of lymphocytes from patients with leprosy. Clin exp Immunol, 1980; 41: 406-14.

50 Moretta L, Webb SR, Grossi CE, Lydyard PM, Cooper MD. Functional analysis of two human T-cell subpopulations: help and suppression of B-cell responses by T cells bearing receptors for IgM and IgG. $J$ exp Med, 1977; 146: 184.

51 Singh S, Nath I. Reduction of a subset of T cells bearing Fc receptors for $\mathrm{IgG}$ in lepromatous leprosy. Int Arch Allergy Appl Immunol, 1980; 62: 81-5.

52 Scheper RJ, Parker D, Noble B, Turk JL. The relation of immune depression and B-cell stimulation during the development of delayed type hypersensitivity to soluble antigens. Immunology, 1977; 32: 265-72.

53 Nath I, van Rood JJ, Mehra NK, Vaidya MC. Natural suppressor cells in human leprosy. The role of HLA-D identical peripheral lymphocytes and macrophages in the in vitro modulation of lymphoproliferative responses. Clin exp Immunol, 1980; 42: 203-10.

54 Narayanan RB, Bhutani LK, Sharma AK, Nath I. T-cell subsets in leprosy lesions: in situ characterisation using monoclonal antibodies. Clin exp Immunol, 1983; 51: 421-29.

55 Stoner GL, Mshana RN, Touw J, Belehu A. Studies on the defect in CMI in lepromatous leprosy using HLA-D-identical siblings. Absence of circulating suppressor cells and evidence that the defect is in the T-lymphocyte rather than the monocyte population. Scand J Imm, 1982; 15: 33-48.

56 Stoner GL, Atlaw T, Touw J, Belehu A. Antigen-specific suppressor cells in subclinical leprosy infection. Lancet, 1981; 2: 1372-7.

56b Bullock WE, Watson S, Nelson KE, Schauf V, Makonkawkeyoon S, Jacobson RR. Aberrant immunoregulatory control of B lymphocyte function in lepromatous leprosy. Clin. exp. Immunol, 1982; 49: 105-114. 
57 Shannon EJ, Powell MD, Jacobson RR, Hastings RC. Investigations of suppressor mechanisms in clinical leprosy. Dermatologia, Revista Mexicana, 1981; 125: 457-68.

58 Bach MA, Chatenoud L, Wallach D, Phan Dinh Tuy F, Coltenot F. Studies on T-cell subsets and functions in leprosy. Clin exp Immunol., 1981; 44: 491-8.

59 Beiguelman B. Leprosy and genetics. Bull Wld Hlth Org, 1967; 37: 461-76.

${ }^{60}$ Godal T, Rees RJW. Fate of $M$. leprae in macrophages of patients with lepromatous or tuberculoid leprosy. Int J Lepr, 1970; 38: 439-41.

${ }^{61}$ Samuel DR, Godal T, Myrvang B, Song YK. Behaviour of M. leprae in human macrophages in vitro. Infect Immunity, 1973; 8: 446-9.

${ }^{62}$ Hirschberg $\mathrm{H}$. The role of macrophages in the lymphoproliferative response to $M$. leprae in vitro. Clin exp Immunol, 1978; 34: 46-51.

${ }^{63}$ Nath I. Mechanisms underlying unresponsiveness to M. leprae: the role of suppressor T cells and adherent cells in human leprosy. 6th IMMLEP Scientific Working Group Meeting WHO, Geneva, 1982.

${ }^{64}$ Birdi TJ, Salgame PR, Antia NH. The role of macrophages in leprosy as studied by protein synthesis of macrophages from resistant and susceptible hosts-a mouse and human study. Lepr India, 1979; 51: 23-42.

65 Birdi TJ, Salgame PR, Mahadevan PR, Antia NH. The role of macrophages in defective CMI in lepromatous leprosy. II. Macrophage and lymphocyte interaction. Int J Lepr, 1980; 48: $178-82$.

${ }^{66}$ Salgame PR, Birdi TJ, Mahadevan PR, Antia NH. Role of macrophages in defective CMI in lepromatous leprosy. I. Factors affecting protein synthesis and lymphocyte transformation. Int J Lepr, 1980; 48: 171-7.

67 Thorsby E, Godal T, Myrvang B. HLA antigens and susceptibility to diseases. II. Leprosy. Tissue Antigens, 1973; 3: 373-8.

${ }^{68}$ Escobar-Gutierrer A, Gorodizky C, Salazar-Mallen M. Distribution of the HLA system lymphocyte antigens in Mexicans. II. Studies in atopics and lepers, 1973. Vox Sang, 1973; 25: $151-5$.

${ }^{69}$ Rea TH, Levan NE, Terasaki PI. Histocompatibility antigens in patients with leprosy. $J$ Infect Dis 1976; 134: 615-18.

${ }^{70}$ Greiner J, Schleiermacher E, Smith T, Lenhard V, Vogel F. The HLA system and leprosy in Thailand. Hum Genet, 1978; 42: 201-3.

${ }^{71}$ Chan SH, Oon BB, Kamarudin A, Wee GB. HLA and leprosy in Chinese. Tissue Antigens, 1979; 13: 73-4.

72 Dasgupta A, Mehra NK, Ghei SK, Vaidya MC. Histocompatibility antigens (HL-A) in leprosy. Tissue Antigens, 1975; 5: 85-7.

73 Youngchaiyud U, Chandanayinyoung D, Vibhatavanija T. The incidence of HLA antigens in leprosy. Vox Sang, 1977; 32: 342-5.

74 DeVries RRP, Lai A Fat RFM, Nijenhuis LE, Van Rood JJ. HLA-linked genetic control of host response to M. leprae. Lancet, 1976; 2: 1328-30.

75 DeVries RRP, Mehra NK, Vaidya MC, Gupte MD, Meera Khan P, Van Rood JJ. HLAlinked control of susceptibility to tuberculoid leprosy. Tissue Antigens, 1980; 16: 294304.

76 Fine PEM, Wolf E, Pritchard J, Watson B, Bradley DJ, Festenstein H, Chacko CJG. HLA-linked genes in leprosy: a family study in a South Indian population. J Infect Dis, 1979; 140: $152-61$.

77 Van Eden W, DeVries RRP, Mehra NK, Vaidya MC, D’Amaro J, Van Rood JJ. HLA segregation of tuberculoid leprosy: confirmation of DR2 marker. J Infect Dis, 1980; 141: 693-701.

78 Van Eden W, Mehra NK, Vaidya MC, D'Amaro J, Schreuder GMT, Van Rood JJ. HLA and 
sporadic tuberculoid leprosy: a population study in Maharashtra, India. Tissue Antigens, 1981; 18: 189-93.

${ }^{79}$ Rea TH, Terasaki P. HLA-DR W antigens in Mexican patients with leprosy, 1979. 14th Joint Conference on Le prosy Research, US-Japan Cooperative Medical Science Programme, pp. 242-5.

${ }^{80}$ Sugiyama K, Izumi S, Matsumoto T, Okhawa S, Matsumoto H, Miyazaki T, Juji T, Maeda H. Analysis of the immunogenetic background of Japanese leprosy patients by HLA and serum protein allotypes. 15th Joint Conference on Leprosy Research, US-Japan Cooperative Medical Science Programme.

81 Van Eden W, deVries RRP, D’Amaro J, Schrender I, Leiker DL, van Rood JJ. HLA-DR-associated genetic control of the type of leprosy in a population from Surinam. Human Immunol, 1982; 4: 343-50.

82 Stoner GL, Touw J, Belehu A, Naafs B. In vitro lymphoproliferative response to M. leprae of HLA-D identical siblings of lepromatous leprosy patients. Lancet, 1978; ii: 543-7.

${ }^{83}$ Ridley MJ, Ridley DS, Turk JL. Surface markers on lymphocytes and cells of the mononuclear phagocyte system in skin sections in leprosy. J. Pathol, 1978; 125: 91-8.

${ }^{84}$ Gupta SK, Bhutani LK, Nath I. The in situ characterisation of mononuclear cell infiltrates in dermal lesions of leprosy. Int J Lepr, 1982; 50: 297-305.

${ }^{85}$ Modlin RL, Hofman FM, Meyer PR, Sharma OP, Taylor CR, Rea TH. In situ demonstration of T-lymphocyte subsets in granulomatous inflammation: leprosy, rhinoscleroma and sarcoidosis. Clin exp Immunol, 1983; 51: 430-38.

${ }^{86}$ Van Voorhis WC, Kaplan G, Sarnee EN, Horwitz MA, Steinman RM, Levis WR, Nogueira N, Hain LS, Gattass CR, Arrick BA, Cohn ZA. The cutaneous infiltrates of leprosy: cellular characteristics and the predominant T-cell phenotypes. N Eng J Med, 1982, 307: 1593-7.

87 Ridley MJ, Ridley DS. Unique expression of HLA-DR (Ia-like) antigen in the lesion of polar tuberculoid leprosy. Lepr Rev, 1982; 53: 249-52.

${ }^{88}$ Faber WR, Leiker DL. Immunofluorescence studies across the leprosy spectrum. Arch Dermatol Res, 1978; 26: 45-53.

89 Bullock WE, Ho MF, Chen MJ. Studies of immune mechanisms in leprosy. J Lab Clin Med, 1970; 75: 863-70.

90 Hastings RC, Morales MJ, Shannon EJ, Jacobson RR. Preliminary results on the safety and efficacy of transfer factor in leprosy. Int J Lepr, 1976; 44: 275.

${ }^{91}$ Hastings RC, Job CK. Reversal reactions in lepromatous leprosy following transfer factor therapy. Amer J Trop Med Hyg, 1978; 27: 995-1004.

92 Han SH, Tsai LC, Hu SC, Loo ST. Conversion of reactions to leprolin and lepromin in patients with lepromatous leprosy by the transfer factor. Chung Hua Min Kuo Wei Sheng WuChi Mien I Hsueh Tsa Chih, 1980; 13 (1): 1-8.

${ }^{93}$ Lim SD, Fusaro R, Good RA. Leprosy VI. The treatment of leprosy patients with intravenous infusions of leukocytes from normal persons. Clin Immunobiol Immunopathol, 1972; 1: 122-39.

94 Saha K, Dutta RN, Dutta AK, Mohan TK. Reversal reaction in patients with lepromatous leprosy after transplantation of human fetal thymic grafts. Vox Sang, 1978; 35: 81-90.

95 Convit J, Aranzazu N, Pinardi M, Ulrich M. Immunological changes observed in indeterminate and lepromatous patients and Mitsuda negative contacts af ter the inoculation of a mixture of M. leprae and BCG. Clin exp Immunol, 1979; 36: 214-20.

${ }^{96}$ Convit J, Aranzazu N, Ulrich M, Aragon ME, Alvarado J, Zuniga M, Reyeso O, Tellez S. Immunotherapy of leprosy. 6th IMMLEP Scientific Working Group Meeting, WHO, Geneva, 1982.

97 Talwar GP. Concluding comments on development of a vaccine against leprosy. Lepr India, 1978; 50: 597-8.

${ }^{98}$ Deo MG, Bapat CV, Chulawalla RG, Bhakti WS. Potential antileprosy vaccine from killed ICRC bacillus. Ind J Med Res, 1981; 74: 164-77. 